\title{
ELECTROSPUN PROTEIN NANOFIBERS AND THEIR FOOD APPLICATIONS
}

Atike İnce Yardımcı, Technology Transfer Office, Usak University, Turkey, atike.yardimci@usak.edu.tr (iD https://orcid.org/0000-0001-5482-4230)

Özgür Tarhan*, Department of Food Enginerring, Usak University, Turkey, ozgur.tarhan@usak.edu.tr (iD) https://orcid.org/ 0000-0001-7084-6253)

Received: 04.05.2020, Accepted: 10.08.2020

Review Article

*Corresponding author DOI: $10.22531 /$ muglajsci.731979

\begin{abstract}
Electrospun nanofibers with their large surface area, high porosity, small pore sizes, and ability of the high loading of active agents possess many structural and functional advantages for food applications. Proteins play significant roles in physicochemical and structural properties in foods. There has been a great interest in using proteins for the fabrication of nanofibers through electrospinning technique. Due to their molecular weight, most of the proteins are non-spinnable alone however; their spinnability can be enhanced by the incorporation of food-grade biocompatible polymers. In this review, the basics of the electrospinning technique were introduced first, followed by detailed information about electrospun nanofibers formed using plant and animal proteins. Common polymers blended with proteins to enhance their spinnability were also discussed. It the last part, the use of electrospun nanofibers in various food applications such as encapsulation of bioactive components, enzyme immobilization, and food packaging was emphasized.

Keywords: Electrospinning, Proteins, Nanofibers, Food Applications

\section{ELEKTROLİF ÇEKIM YÖNTEMİ İLE ELDE EDİLMIŞ PROTEİNLER VE ONLARIN GIDA UYGULAMALARI}

\section{Özet}

Elektrolif çekim yöntemi ile elde edilmiş nanolifler yüksek yüzey alanları, düşük gözenek boyutu ve yüksek miktarda aktif ajan yüklenebilme kapasiteleriyle gıda uygulamaları için yapısal ve fonksiyonel olarak birçok ajantaj sağlamaktadırlar. Elektrolif çekim yöntemi ile nanolif eldesinde proteinlerin kullanılması son yıllarda büyük ilgi görmektedir. Moleküler ağırlıkları sebebiyle çoğu protein kendi başına elektrolif çekim yönteminde lif oluşumunu sağlayamamaktadır, bununla beraber gida sinıfinda bir biyopolimerle desteklenerek proteinlerde nanolif sentezi yapılabilmektedir. Bu derlemede ilk olarak elektrolif çekim yönteminin temellerine değinilmiştir. Sonrasında, bitkisel ve hayvansal proteinlerden elde edilen nanoliflerle ilgili detaylı bilgi verilmiștir. Proteinlerle birlikte kullanılan ve onların çekilebilirliğini iyileștiren yaygın polimerler de tartışılmıştır. Çalışmanın son kısımda, elektrolif çekim yöntemi ile elde edilmiş nanoliflerin, biyoaktif malzemelerin kapsüllenmesi, enzim immobilizasyonu ve gıda paketlemesi gibi farklı gıda uygulamalarında kullanımları vurgulanmiştır.

Anahtar Kelimeler: Elektrolif çekim yöntemi, Protein, Nanolif, Gıda uygulamaları

Cite

İnce, Yardımcı, A., Tarhan Ö., (2020). "Electrospun protein nanofibers and their food applications", Mugla Journal of Science and Technology, 6(2),52-62.

\section{Introduction}

There are various methods to synthesize nanofibers (NFs) with desirable features reported in the literature. Some of the conventional methods are plasma polymerization, evaporation, sputter deposition, laser ablation, and wet chemical methods. Besides these, selfassembly [1-3], melt fibrillation [4], centrifugal spinning [5], nanolithography are the recent fiber synthesis methods. These methods are generally applicable for a few polymers and can exhibit difficulties in processing. Electrospinning can be defined as a simple and robust fiber synthesis technique for the fabrication of long organic fibers based on high electrical fields. It was first conducted by Anton Formhals in 1934 to synthesize cellulose acetate fibers [6]. In this technique, a charged jet was created from a polymer solution under a high electrical field to produce fibers with a diameter range of micro and nanometer [7]. Fibers obtained by electrospinning possess many desirable structural properties such as extremely high surface to volume ratio, surface charge, and special dimension. Therefore, they can be used for various purposes in many application areas such as catalysis in the chemical industry [8], scaffolding in tissue engineering $[9,10]$, protective clothing in textile industry [11], filtration in 
process industries [12, 13], biomedical and biotechnology [14-16], optical electronics [17], and food technology [18] as well. Among them, food-related applications of electrospun fibers are in the focus of many researches. Due to their safety, proteins are one of the ideal materials to be used for the fabrication of micro/nanofibers via electrospinning. Besides their structural advantages, nanoscale protein fibers have also significant functional properties enabling them to act as great matrices in food processing and preservation. In this study, a detailed discussion about the manufacturing of electrospun protein NFs and their applications, especially in the food industry have been presented based on the literature studies indexed in the international databases and published in the last two decades.

\section{Electrospinning}

Electrospinning is a fiber production method which uses electrical forces to obtain micro/nanoscale polymer strands. Three main parts of the electrospinning setup are a DC high voltage supply, a syringe pump, and a grounded collector [19]. In the electrospinning process, a high voltage passes from a polymer solution filled into a syringe through a grounded collector. The polymer solution is pumped while the voltage is on, then an electric charge is created onto the polymer solution. The polymer solution drop is affected by two types of electrostatic forces: mutual electrostatic repulsion between the surface charges and the Coulombic force applied by the external electric field. These electrostatic forces cause the liquid drop to elongate into a conical shape called as Taylor cone. A charged polymer jet is ejected from Taylor cone and reaches to the collector by following an unstable way through the collector. Consequently, nano- or micro-scaled polymer fibers are deposited on the collector surface [20]. A schematic drawing of an electrospinning setup and a scanning electron microscopy (SEM) image of a typical electrospun NFs are given in Fig. 1.

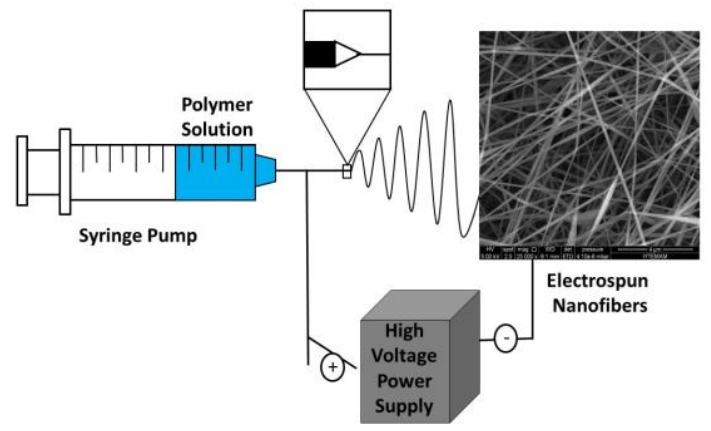

Figure 1. Schematic of a typical electrospinning system and an SEM image of typical electrospun fibers.

Polyacrylonitrile (PAN)/ polypyrrole (PPy)

bicomponent NFs are shown in the figure.

In electrospinning process solution properties, process factors, and ambient conditions are the main parameters affecting the mechanics of the fiber formation and fiber properties [21]. Critical parameters of the polymer solutions are concentration, viscosity, conductivity, and surface tension. Setting up the optimum polymer concentration is significant for a successful fiber formation. It influences surface tension and fiber morphology as well. At very low concentrations desirable fiber formation does not occur, instead, beads on the fibers can be seen due to the capillary breakup of the jet by the surface tension [22]. With the increasing polymer concentration, the fiber diameter also increases. Moreover, at very high polymer concentration, continuous flow of the solution through the spinneret is disabled, and therefore continuous fiber formation does not occur [23]. The molecular weight of the polymer defines the number of entanglements of the polymer chains, thus polymers with high molecular weight can exhibit good spinnability and desirable fiber formation [24]. Solution viscosity should also be optimized for getting target fibers. In the case of high viscosity, electrostatic forces cannot overcome the surface tension, therefore continuous fiber formation can not be achieved. In case of low solution viscosity, shorter stress relaxation time is obtained and this results in bead formation. Solution conductivity can be defined by polymer type, solvent, and the presence of ionizable salts in the solution. Generally, high electrical conductivity can provide the formation of uniform fibers with a smaller diameter. However, if the solution is very conductive, it may cause instability in the electrical field and significant bending of the polymer jet at Taylor cone. Thereby, the resultant fibers might have a larger diameter [25].

Process parameters consist of applied voltage, distance between the syringe and the collector, emitting electrode polarity, and solution flow rate. Optimum voltage varies for different polymer/solvent systems [21]. For example, while increasing voltage causes thick fibers for polyvinyl alcohol (PVA)/water solution [26], it narrows the diameter of fibers for polysulfone amide (PSA)/ dimethylacetamide (DMAC)/ water solution [27]. Thus, voltage influences fiber morphology significantly based on the polymer system used. The solution flow rate is another important parameter. At high flow rates solution does not have enough time to evaporate until it reaches the collector. This causes bead formation and thicker fibers. However, at low flow rates solution can polarize easily and better fiber morphology can be obtained [28, 29]. The quite short distance between the tip of the syringe and the collector also does not allow the solvent to evaporate before reaching the collector, thus increases fiber diameter and bead formation [30]. Lastly, temperature, humidity, and velocity of the air are the ambient conditions affecting fiber formation [31].

\section{Protein-Based Electrospun Materials}


Food proteins show significant importance due to their non-toxicity, biocompatibility, biodegradability, and absorbability properties. They can contain certain biochemical information as well [32]. However, while the active proteins are applied directly to the foods, other components within the food matrix and environmental agents can cause inactivation of them [33]. Besides, proteins have complex secondary and tertiary structures which may prevent them to be electrospun on their own. While some proteins could be electrospun alone, some of them need to be incorporated with a spinnable co-polymer to produce NFs. Besides aiding fiber synthesis during electrospinning, utilized polymers can also improve the mechanical properties of the resultant NFs. Interactions of proteins with natural polyphenols have been provided by hydrophobic interactions and hydrogen bonding and these interactions are very strong [34]. Therefore the stability of the protein fibers can be enhanced by the addition of polyphenols [35].

The mechanism of the formation of electrospun protein NFs and their properties have been reported in the literature [36, 37]. The most important parameters in protein spinnability are protein structure, aggregation property, and the Exchange of intra/intermolecular disulfide bonds. Spinnability and the features of the protein NFs can be controlled by the manipulation of the protein conformation and aggregation. The highest molecular weight proteins are responsible for lower threshold concentrations for fiber formation [38]. A low viscosity protein solution can be modified into a spinnable solution and readily fibers which can indicate good mechanical properties like natural fibers made of fibrous proteins [39]. The fiber formation mechanism is mainly based on the chain entanglements and reversible junctions of the protein subunits with the breaking and reforming of disulfide bonds existing in the protein structure.

Plant proteins and animal proteins are two main groups referring to food grade proteins with different structural and functional properties.

\subsection{Plant Proteins}

Soy protein, zein, wheat gluten, and amaranth protein are some common plant proteins used for nanoscale fiber formation. As stated above, mostly they are combined with different polymers to enhance spinnability and produce desirable NFs. Table 1 briefly summarizes recent NF studies conducted using plant proteins and their copolymers. Polyvinyl alcohol (PVA) is one of the most common polymers used with soy protein isolate (SPI) in the electrospinning process. SPI/PVA NF studies indicated that while SPI content was kept constant, a high solution $\mathrm{pH}$ level caused denaturation of the protein and decreased the average diameter of fibers [40]. Poly(ethylene oxide) (PEO) is another polymer frequently used with SPI to increase its spinnability. Anthocyanin-rich red raspberry extract (ARRE) incorporated SPI/PEO NFs were studied successfully [41]. ARRE incorporation after SPI denaturation provided fiber formation with excellent antibacterial activity against Staphylococcus epidermidis. These NFs were proposed as active and safe nanomaterials in the food systems. Pea protein isolate (PPI) was electrospun with carbohydrate polymer pullulan by using a green electrospinning technique [42]. FT-IR spectra and XRD patterns of the resulted NFs indicated that the protein and the polysaccharide were found in the entangled form. Thermal crosslinking of NFs was also examined and the thermally treated nanofibrous mats showed preferable hydrophobicity compared to the non-crosslinked samples. Zein, another plant protein, shows poor water resistance which limits its applications in food preservation. Zein was electrospun with ethyl cellulose (EC), as a co-polymer, to improve its water resistance [43]. The cinnamon essential oil was encapsulated in zein/EC NFs for preservation against Agaricus bisporus. With the increasing ratio of EC to zein from 0 to $100 \mathrm{wt} \%$, solution viscosity gradually increased by providing enough chain entanglement to prepare uniform fibers. The hydrogen bonds between the hydroxyl groups of EC and the amino groups of zein reduced the content of free hydrophilic groups and resultantly increased water resistance of NFs was achieved. Also, the antifungal food packaging potential of zein/EC NFs was investigated against Agaricus bisporus. In another study, allopurinol encapsulated glucose cross-linked zein/gelatin NFs were reported as a delivery system for hydrophobic bioactive molecules [44]. Sunflower protein isolate (SFPI)/PVA NFs were reported with their hydrophobicity based on contact angle tests [45]. FTIR analysis investigated the denaturation of protein and interactions between protein and PVA after heat treatment. Aceituno-Medina et al. [46] examined amaranth protein isolate (API) to form electrospun NFs. Fibril-like morphologies were only obtained when hexafluoro-2-propanol was utilized as a solvent to dissolve API. Hexafluoro-2-propanol supported the formation of random coil structures and provided an enhancement in the entanglements of the biopolymer.

Table 1. Plant protein-based electrospun materials.

\begin{tabular}{|l|l|l|l|}
\hline Protein & Polymer & Results & References \\
\hline SPI & PVA & $\begin{array}{l}\text { Thinner fibers } \\
\text { formed via } \\
\text { using the same } \\
\text { SPI amount, at } \\
\text { higher solution } \\
\text { pH. }\end{array}$ & $\begin{array}{l}\text { Cho et al., } \\
\text { 2012 [40] }\end{array}$ \\
\hline SPI & PEO & $\begin{array}{l}\text { SPI/PEO NFs } \\
\text { with ARRE } \\
\text { indicated } \\
\text { antibacterial } \\
\text { activity against } \\
\text { S. epidermidis. }\end{array}$ & Wang et al., \\
& & $\begin{array}{l}\text { Well- } \\
\text { entanglement }\end{array}$ & $\begin{array}{l}\text { Wen Jia et } \\
\text { al., 2019 }\end{array}$ \\
\hline PPI & Pullulan & & \\
\hline
\end{tabular}




\begin{tabular}{|c|c|c|c|}
\hline & & $\begin{array}{l}\text { of protein and } \\
\text { polysaccharide } \\
\text { achieved in } \\
\text { NFs. }\end{array}$ & [42] \\
\hline Zein & EC & $\begin{array}{l}\text { Food packaging } \\
\text { potential of } \\
\text { zein/EC NFs } \\
\text { presented } \\
\text { against } A \text {. } \\
\text { bisporus. }\end{array}$ & $\begin{array}{l}\text { Niu et al., } \\
2020 \text { [43] }\end{array}$ \\
\hline Zein & Gelatin & $\begin{array}{l}\text { Glucose cross- } \\
\text { linked } \\
\text { zein/gelatin } \\
\text { NFs with } \\
\text { promising } \\
\text { delivery } \\
\text { systems for } \\
\text { hydrophobic } \\
\text { bioactives. }\end{array}$ & $\begin{array}{l}\text { Deng et al., } \\
2019 \text { [44] }\end{array}$ \\
\hline Zein & Gelatin & $\begin{array}{l}\text { Significantly } \\
\text { increased } \\
\text { diameter of } \\
\text { gelatin/zein } \\
\text { NFs with the } \\
\text { increasing } \\
\text { gelatin amount. }\end{array}$ & $\begin{array}{l}\text { Deng et al., } \\
2017 \text { [47] }\end{array}$ \\
\hline SFPI & PVA & $\begin{array}{l}\text { Production of } \\
\text { hydrophobic \& } \\
\text { hydrophilic } \\
\text { NFs with } \\
\text { sunflower } \\
\text { protein by- } \\
\text { product. }\end{array}$ & $\begin{array}{l}\text { Shanesazza } \\
\text { deh et al., } \\
2018 \text { [45] }\end{array}$ \\
\hline API & $\begin{array}{l}\text { Glacial } \\
\text { acetic } \\
\text { acid }\end{array}$ & $\begin{array}{l}\text { Capsule } \\
\text { morphologies } \\
\text { obtained at pH } \\
\text { of } 2 \text { and } 12 . \\
\text { Fiber-like } \\
\text { morphologies } \\
\text { obtained only } \\
\text { using solvent } \\
\text { hexafluoro-2- } \\
\text { propanol. }\end{array}$ & $\begin{array}{l}\text { Aceituno- } \\
\text { Medina et ., } \\
2013 \text { [46] }\end{array}$ \\
\hline $\begin{array}{l}\text { Wheat } \\
\text { gluten }\end{array}$ & PVA & \begin{tabular}{|l} 
Nisin-loaded \\
PVA/wheat \\
gluten/zirconia \\
NFs with well- \\
controlled \\
release and \\
better \\
antimicrobial \\
activity against \\
S.aureus
\end{tabular} & $\begin{array}{l}\text { Wang et al., } \\
2015 \text { [48] }\end{array}$ \\
\hline
\end{tabular}

\subsection{Animal Proteins}

Well-known electrospinnable animal-based proteins are whey protein, gelatin, casein, silk fibroin, tussah silk, elastin, keratin, bovine serum albumin, collagen, hemoglobin. Like plant proteins, some animal proteins have also been blended with polymers to produce NFs. Table 2 briefly summarizes recent NF studies performed using animal proteins with or without polymers. Whey protein isolate (WPI) was electrospun with betalactoglobulin $(\beta-\lg )$ and PEO [49]. PEO supported the formation of NFs with an average diameter ranging from 312 to $690 \mathrm{~nm}$. This study indicated that WPI/PEO NFs protected their fiber morphology during thermal treatment up to $100{ }^{\circ} \mathrm{C}$, although the melting point of PEO is $60^{\circ} \mathrm{C}$. The researchers have suggested WPI/PEO $\mathrm{NFs}$ for use in regenerative medicine applications since nanofibrous mats swell in water and retain a fibrous quality. Food protein fibers were obtained from mixing maltodextrin (MD) with both WPI and SPI through the synthesis in a needleless electrospinning setup by Kutzli et al. [50]. They examined different maltodextrin to protein ratios and their results showed that higher protein content usually provided higher solution conductivity and viscosity. The high viscosity complicated electrospinning process, and thus the MD/SPI fibers had lower production rates and higher diameters compared to MD/WPI fibers. Their findings indicated that the protein type and content in the spinning dispersion affected the production rate and structure of the fibers. Gelatin is another animal-based protein which could be electrospun to obtain NFs with high potential for many applications. Talebian and coworkers used gelatin and gelatin/chitosan nanofibrous mats for drug (vancomycin) delivery [51]. Vancomycin loaded gelatin NFs achieved drug delivery in high percentages. However, chitosan addition in gelatin NFs caused a decrease in vancomycin release. Gelatin NFs containing thyme essential oil/ $\beta$-cyclodextrin $\varepsilon$ polylysine nanoparticles (TCPNs) were examined to control Campylobacter jejuni [52]. TCPNs showed high antimicrobial activity against $C$. jejuni. Then, these antimicrobial gelatin NFs were used for meat packaging. The results indicated that TCPNs incorporated gelatin NFs were appropriate for meat preservation without affecting the sensorial properties of the meat. EC/gelatin with different content of zinc oxide $(\mathrm{ZnO})$ nanoparticles was electrospun [53]. The antibacterial assay of these NFs displayed that concentration of $\mathrm{ZnO}$ on the viabilities of Escherichia coli and Staphylococcus aureus was significant. The $\mathrm{ZnO}$-containing gelatinbased nanofibers indicated surface hydrophobicity, water stability, and antimicrobial activity, promising for the potential use in food packaging. Scanning Electron Microscope (SEM) images of gelatin electrospun NFs were shown in Figure 2.

Casein is another animal protein used for NF formation [54]. The feasibility of fiber synthesis from aqueous solutions of calcium (CaCAS) and sodium (NaCAS) caseinate with and without pullulan was examined. It was reported that in case of CaCAS or NaCAS solutions alone no fiber formation was observed due to insufficient chain entanglements, however, the addition of pullulan to casein provided fiber formation. Esparza 
et al. recovered ceratine from the chicken feather in aqueous alkaline conditions and they synthesized NFs by mixing ceratine with PVA/citric acid solution using electrospinning technique [55]. Increasing the ceratine amount in the solution ( 0 to $20 \mathrm{wt} \%$ ) resulted in a decrease in the fiber diameter (from $565 \mathrm{~nm}$ to 274 $\mathrm{nm}$ ). However, increasing ceratine ratio caused bead formation on NFs. These ceratine/PVA NFs were examined for fibroblast proliferation and regraded as appropriate scaffolds for fibroblast accommodation.
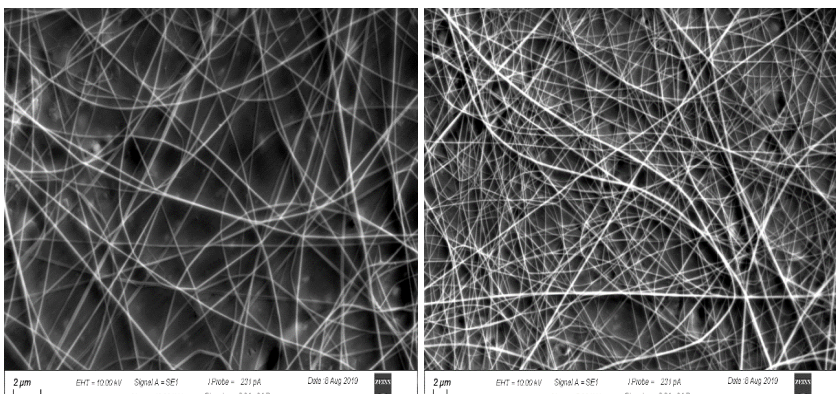

Figure 2.SEIM Images of electrospun gelatin NFS at different magnifications.

Fibrinogen as a naturally occurring blood protein is a good candidate in NF form for use in tissue engineering [56-58], wound dressing, drug delivery, and hemostatic bandage applications [59] due to its low immunogenicity, biodegradability, and native cellbinding domains. Besides, fibrinogen NFs were reported with viscoelastic behavior which favors cell attachment and the potential for remodeling [60]. As a marine originated protein, fish sarcoplasmic proteins were examined in the NF form for oral drug applications [37]. The Spirulina microalga with its high protein content was utilized to obtain antioxidant ultrafine electrospun NFs for food preservation [61].

Table 2. Animal protein-based electrospun NFs

\begin{tabular}{|c|c|c|c|}
\hline Protein & Polymer & Results & References \\
\hline WPI & PEO & $\begin{array}{l}\text { WPI with PEO } \\
(1 \% \text { w/w) NFs } \\
\text { obtained with } \\
\text { diameters } \\
\text { ranging btw } \\
100 \text { and } 400 \\
\text { nm. }\end{array}$ & $\begin{array}{l}\text { Zhong et } \\
\text { al., } 2018 \\
{[62]}\end{array}$ \\
\hline WPI & PEO & $\begin{array}{l}\text { WPI/PEO (3:1) } \\
\text { resulted in } \\
\text { fibers with } \\
\text { average } \\
\text { diameters } \\
\text { ranging from } \\
312 \text { to } 690 \mathrm{~nm} \text {, } \\
\text { and appropriate } \\
\text { matrices for } \\
\text { regenerative }\end{array}$ & $\begin{array}{l}\text { Sullivan et } \\
\text { al., } 2014 \\
{[49]}\end{array}$ \\
\hline
\end{tabular}

\begin{tabular}{|c|c|c|c|}
\hline & & medicine. & \\
\hline WPI & MD & $\begin{array}{l}\text { MD/SPI NFs } \\
\text { with lower } \\
\text { fabrication } \\
\text { rates and higher } \\
\text { diameters when } \\
\text { compared to } \\
\text { MD/WPI NFs. }\end{array}$ & $\begin{array}{l}\text { Kutzli et } \\
\text { al., } 2019 \\
{[50]}\end{array}$ \\
\hline Gelatin & Chitosan & $\begin{array}{l}\text { Gelatine NFs } \\
\text { with higher } \\
\text { vancomycin } \\
\text { delivery } \\
\text { potential in } \\
\text { comparison to } \\
\text { gelatin/chitosan } \\
\text { NFs. }\end{array}$ & $\begin{array}{l}\text { Talebian } \\
\text { et al., } 2017 \\
{[51]}\end{array}$ \\
\hline Gelatin & - & $\begin{array}{l}\text { Functional } \\
\text { nanoparticle } \\
\text { incorporated } \\
\text { antimicrobial } \\
\text { gelatin NFs for } \\
\text { preservation of } \\
\text { chicken meat. }\end{array}$ & $\begin{array}{l}\text { Lin et al., } \\
2018 \text { [52] }\end{array}$ \\
\hline Gelatin & EC & $\begin{array}{l}\text { ZnO } \\
\text { incorporated } \\
\text { gelatin/EC NF } \\
\text { with surface } \\
\text { hydrophobicity, } \\
\text { water stability, } \\
\text { and } \\
\text { antimicrobial } \\
\text { activity. }\end{array}$ & $\begin{array}{l}\text { Liu et al., } \\
2018 \text { [53] }\end{array}$ \\
\hline Casein & Pullulan & $\begin{array}{l}\text { Fiber formation } \\
\text { from casein } \\
\text { using pullulan, a } \\
\text { food grade } \\
\text { carrier. }\end{array}$ & $\begin{array}{l}\text { Tomasula } \\
\text { et al., } 2016 \\
{[54]}\end{array}$ \\
\hline $\begin{array}{l}\text { Silk } \\
\text { Fibroin }\end{array}$ & - & $\begin{array}{l}\mathrm{NaCl} \text { added silk } \\
\text { fibroin NFs to } \\
\text { be used for skin } \\
\text { tissue } \\
\text { engineering. }\end{array}$ & $\begin{array}{l}\text { Park et al., } \\
2016 \text { [63] }\end{array}$ \\
\hline Collagen & Chitosan & $\begin{array}{l}\text { Collagen- } \\
\text { chitosan NFs } \\
\text { supported both } \\
\text { endothelial and } \\
\text { smooth muscle } \\
\text { cell } \\
\text { proliferation. }\end{array}$ & $\begin{array}{l}\text { Chen et al., } \\
2010 \\
{[64]}\end{array}$ \\
\hline Keratin & PVA & $\begin{array}{l}\text { Ceratine/PVA } \\
\text { NFs supported } \\
\text { fibroblast } \\
\text { proliferation. }\end{array}$ & $\begin{array}{l}\text { Esparza et } \\
\text { al., } 2017 \\
{[55]}\end{array}$ \\
\hline
\end{tabular}

4. Electrospun Protein Fibers For Food Applications Due to their structural and functional properties, electrospun protein fibers can be used for various food applications including encapsulation of food bioactive 
compounds, immobilization of enzymes, and packaging of food materials. Those common applications are discussed below.

\subsection{Encapsulation of food bioactives}

Encapsulation of bioactive agents for the purpose of incorporation into foods is very important for food processing. Encapsulation is a process in which active agents such as food bioactive molecules or living cells are capped or coated within a carrier material such as carbohydrate, protein, and lipids based polymers via micro or nanometer scale particles or capsules. Encapsulation of bioactive compounds provides protection of them from environmental stress and enhancement of their physicochemical functionalities, stability, and bioavailability. Electrospinning is a promising technique for encasing food bioactives since it is a feasible method to produce dry, food-grade, and nano-scaled materials with high encapsulation efficiencies. [65]. For the encapsulation systems, envelope matrices should be made from food-grade materials. Natural biopolymers, protein, and polysaccharide-based electrospun NFs are widely utilized for obtaining encapsulation materials due to their controlled and continuous release properties [66]. Some examples of the electrospun proteins reported in current literature for encapsulation purposes are WPI, SPI, egg albumen, collagen, gelatin, zein, and casein.

Zein/PEO/chitosan NFs were expressed as a vehicle to entrap $\alpha$-tocopherol with improved targeted release and gastro-mucoadhesivity [67]. Chitosan/phospholipid NFs were examined for the controlled release and delivery of curcumin [68]. Chitosan/phospholipid NFs successfully exhibited constant release behavior of curcumin, around $75 \%$ at the end of 7 days. Fabra et al. studied $\alpha$-tocopherol added three different matrices including WPI, SPI, and zein to form NFs through electrospinning. In case of using zein, electrospun NFs were successfully obtained, however, in case of using WPI and SPI electrosprayed capsules were formed [69]. The findings of this work showed that higher encapsulation efficiency of $\alpha$-tocopherol (100\%) was obtained via zein NFs. In another study, zein NFs were used for the encapsulation of fish oil [70]. The encapsulation efficiency of zein fibers was reported as $91 \%$ for ethanol and $96 \%$ for isopropanol used as solvents in the electrospinning process. Besides, encapsulation in electrospun zein NFs improved fish oil oxidative stability. Electrospun zein NFs were also used for curcumin encapsulation [71]. Curcumin (1.6 wt\%) loaded zein NFs exhibited a potential to be used as an antibacterial non-woven mat owing to leading restricted growth of Staphylococcus aureus (83\%). Li et al. studied vitamin A and vitamin E added gelatin NFs [72]. These vitamin incorporated NFs allowed the sustained release of the vitamins for more than $60 \mathrm{~h}$. SPI electrospun fibers were examined for the encapsulation and controlled release of a drug active agents, metformin, 5flourouracil, and diclofenac [73]. According to the findings of the relevant study, compounds with higher affinity for SPI showed a more sustained release rate. Electrospun materials generally show high encapsulation efficiency and sustained release properties. Besides, they provide great thermal, light and storage stability, and protect bioactive compounds from chemical degradation. The bioactive compounds encapsulated in the electrospun fibers show enhanced stability and functionality [74]. Overall, electrospun protein NFs are appropriate materials for the encapsulation of bioactive compounds.

\subsection{Immobilization of industrial enzymes}

Enzymes are both proteins and catalysts possessing a high degree of specificity. Their specificities are basically due to discrimination between substrates, similar parts of molecules, and optical isomers [75]. Enzyme immobilization can be defined as the confinement of an enzyme to a matrix or support different from the one for substrates and products [76]. Nanomaterials can provide an extremely large surface area enabling high immobilization capability, and thus increased efficiency [77]. In the form of a single enzyme nanoparticle, while a nanometer scale network was used for enzyme immobilization, each enzyme molecule is surrounded with a nanometer scale network and it provides stabilization of enzyme activity without any serious limitation for the substrate transfer from solution to the active site. Nanomaterials display some advantages to improve enzyme immobilization processes [78]. Large surface area to volume ratio is the most important advantage of NFs to maximize enzyme loading and to utilize the non-porous nanomaterials capable of providing very little mass transfer limitation. Brownian motions of the nanomaterials may be responsible for high activities obtained when the enzymes are immobilized on nanoparticles. Therefore, the electrospun NFs are appropriate matrices for the enzyme immobilization. Enzymes can be adsorbed or attached to the NF surface with covalent bonds. Crosslinking of the enzymes to the electrospun NFs provides greater residual activity, it provides increased surface area and porosity [79]. Electrospun NFs can also enhance the ability to catalyze the immobilized enzymes. Wu et al. studied the immobilization of cellulase in PVA electrospun nanofibrous membranes [80]. PVA/cellulase nanofibrous membranes were crosslinked by glutaraldehyde vapor and the results showed that the activity of the immobilized cellulase in PVA NFs was increased to $65 \%$ when compared to that of the free enzyme. In the enzyme immobilization process, the immobilized enzymes can only form a monolayer on each NF. In order to solve this problem, Kim et al. studied enzyme-aggregate coatings on polystyrene/ poly(styrene-co-maleic anhydride) (PS/PSMA) NFs, combined with a glutaraldehyde treatment for crosslinking [81]. The findings of $\alpha$ chymotrypsin coated nanofibres revealed that the initial activity of $\alpha$-chymotrypsin -aggregate-coated NFs was 
nine times higher than NFs with one-layer of covalently attached $\alpha$-chymotrypsin molecules.

Immobilization of enzymes provides higher temperature, $\mathrm{pH}$, and storage stabilities compared to their free form [82]. Based on various current works, the use of electrospun NFs for enzyme immobilization is advantageously feasible in the food industry.

\subsection{Food Packaging}

Food packaging provides protection, tampering resistance, and special physical, chemical, and biological needs in order to maintain the longer shelf life of the food products with assured safety and quality by considering the international standards [83]. Packaging of foods suppresses microbial growth, resists against chemical deterioration (eg. oxidation), and protects them from environmental conditions [84]. Electrospun NFs can allow a high amount of active agent loading when used as packaging materials. Besides, their high surface area increases their response to its surrounding conditions with the timely release of active materials. Very small gaps between the electrospun NFs can restrain bacterial entry. Some functional advantages of NFs are high loading capacity, improved stability of sensitive bioactive molecules, and the use of food-grade polymers safely [85]. Zein is one of the most commonly used proteins for making edible films and coatings for food packaging purposes. Shao et al. analyzed the effect of different surfactants on the characteristics of electrospun zein NFs and on the release of cinnamaldehyde essential oil incorporated in zein NFs [86]. Besides, NFs were examined as an antibacterial package for mushrooms. The addition of sodium cetyltrimethylammonium bromide as a surfactant to zein NFs decreased the release of cinnamaldehyde essential oil while the addition of Tween80, lecithin, and sodium dodecyl sulfate accelerated release in ethanol aqueous solution. The NFs blocked the growth of microorganisms and extended the shelf life of mushrooms, it was indicated that these NFs could have the potential to be used as an active antibacterial package. Böhmer-Maas et al. investigated the synthesis of zein/ titanium dioxide $\left(\mathrm{TiO}_{2}\right) \mathrm{NFs}$ and the utilization of these fibers as ethylene absorbers in order to improve the storage of cherry tomatoes [87]. NFs obtained were examined for the ethylene absorption during the storage of cherry tomatoes for 22 days. Containers with a sachet of zein/ $/ \mathrm{TiO}_{2}$ NFs showed a lower concentration of ethylene which indicated that these NFs could be utilized as active food packaging materials. Lin et al. prepared moringa oil-loaded chitosan nanoparticles and embedded them into gelatin NFs for the biocontrol of Listeria monocytogenes and Staphylococcus aureus on cheese [88]. High antibacterial activity against both species was achieved via these NFs at $4{ }^{\circ} \mathrm{C}$ and $25^{\circ} \mathrm{C}$ for 10 days without any effect on the sensory quality of cheese. Therefore gelatin NFs are suggested for the use in food preservation. A typical electrospun gelatin NF is given in Figure 3.
Sani et al. studied the effect of electrospun WPI/cellulose NF nanocomposite films with the incorporation of $1.0 \%$ (w/w) $\mathrm{TiO}_{2}$ and $2.0 \%(\mathrm{w} / \mathrm{v})$ rosemary essential oil (REO) in order to preserve the microbial and sensorial quality of lamb meat during the storage at $\sim 4{ }^{\circ} \mathrm{C}$ [89]. This study indicated that the nanocomposite films provided a reduction in the bacterial counts and the shelf life of the lamb meat was extended from 6 days to 15 days as well.

As a result, protein NFs could be utilized successfully as food packaging materials for the preservation of different foods. Blending with the safe polymers results in increased spinnability and improved structural and mechanical properties of the NFs facilitating the packaging process.

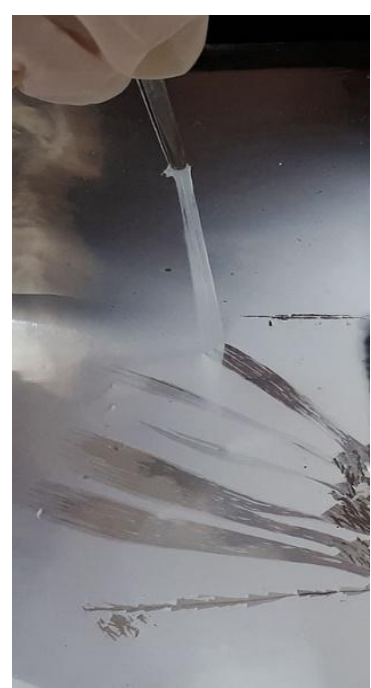

Figure 3. A representative electrospun gelatin NF sheet

\section{Conclusions}

Electrospun protein NFs have great potential for food and medical applications. SPI, zein, wheat, whey, gelatin, and casein are commonly reported food proteins to be electrospun with varying structural composition and physicochemical properties. PVA, PEO, pullulan, ethylcellulose, cyclodextrin, maltodextrin are some polymers mixed with proteins to increase spinnability and support the fiber formation in the electrospinning process. Moreover, these polymers can improve the mechanical properties of the resulting electrospun materials. Incorporating active components to protein NFs, their antimicrobial, antibacterial and antifungal activities could be enhanced. Electrospun protein NFs indicate high encapsulation efficiency and wellcontrolled release properties. The bioactive compounds encapsulated in fibers have improved stability and functionality. Immobilization of enzymes on electrospun NFs successfully increases the catalyzing ability of the enzymes. Lastly, in regards to electrospun NFs food packaging applications, these nanofibrous food grade materials increase the shelf life of foods such as meat, fruit, mushroom, etc without changing their sensorial attributes. Electrospun protein NFs can be served as 
great materials for active food packaging and preservation.

\section{Acknowledgment}

The authors thank Dr. Gamze Tetik (Uşak University), Dr. Elif Özçeri İyikanat (IYTE), and IYTE/MAM for the images of gelatin nanofibers given in figure 2 and 3 .

\section{References}

1. Jun, H.-W., S.E. Paramonov, and J.D. Hartgerink, Biomimetic self-assembled nanofibers, Soft Matter, 2(3), 177-181, 2006.

2. Tarhan, Ö., E. Tarhan, and Ş. Harsa, Investigation of the structure of alpha-lactalbumin protein nanotubes using optical spectroscopy, Journal of Dairy Research, 81(1), 98-106, 2014.

3. Tarhan, Ö. and Ş. Harsa, Nanotubular structures developed from whey- based $\alpha$ - lactalbumin fractions for food applications, Biotechnology progress, 30(6), 1301-1310,2014.

4. Raghavan, B., H. Soto, and K. Lozano, Fabrication of melt spun polypropylene nanofibers by forcespinning, Journal of Engineered Fibers and Fabrics, 8(1) 155892501300800106, 2013.

5. Zhang, X. and Y. Lu, Centrifugal spinning: an alternative approach to fabricate nanofibers at high speed and low cost, Polymer Reviews, 54(4), 677 701, 2014.

6. Anton, F., Process and apparatus for preparing artificial threads, Google Patents, 1934.

7. Prabaharan, M., R. Jayakumar, and S. Nair, Electrospun nanofibrous scaffolds-current status and prospects in drug delivery, in Biomedical applications of polymeric nanofibers, Springer, 241-262, 2011.

8. Formo, E., et al., Functionalization of electrospun $\mathrm{TiO} 2$ nanofibers with $\mathrm{Pt}$ nanoparticles and nanowires for catalytic applications, Nano Letters, 8(2), 668-672, 2008.

9. Ince Yardimci, A., et al. CNT incorporated polyacrilonitrile/polypyrrole nanofibers as keratinocytes scaffold, Journal of Biomimetics, Biomaterials and Biomedical Engineering, Trans Tech Publ., 2019

10. Ince Yardimci, A., et al., Osteogenic differentiation of mesenchymal stem cells on random and aligned PAN/PPy nanofibrous scaffolds, Journal of biomaterials applications, 34(5), 640-650, 2019.

11. Dhineshbabu, N.R., et al., Electrospun $\mathrm{MgO} / \mathrm{Nylon} 6$ hybrid nanofibers for protective clothing, Nano-Micro Letters, 6(1), 46-54, 2014.

12. Shabafrooz, V., et al., Electrospun nanofibers: from filtration membranes to highly specialized tissue engineering scaffolds, Journal of nanoscience and nanotechnology, 14(1), 522-534, 2014.

13. Sundarrajan, S., et al., Electrospun nanofibers for air filtration applications, Procedia Eng, 75, 159$163,2014$.
14. Zafar, M., et al., Potential of electrospun nanofibers for biomedical and dental applications, Materials, 9(2), 73, 2016.

15. Al-Enizi, A.M., M.M. Zagho, and A.A. Elzatahry, Polymer-based electrospun nanofibers for biomedical applications, Nanomaterials, 8(4), 259, 2018.

16. Haider, A., S. Haider, and I.-K. Kang, A comprehensive review summarizing the effect of electrospinning parameters and potential applications of nanofibers in biomedical and biotechnology, Arabian Journal of Chemistry, 1(8), 1165-1188, 2018.

17. Camposeo, A., L. Persano, and D. Pisignano, Light- Emitting Electrospun Nanofibers for Nanophotonics and Optoelectronics, Macromolecular Materials and Engineering, 298(5), 487-503, 2013.

18. Torres-Giner, S., Electrospun nanofibers for food packaging applications, Multifunctional and nanoreinforced polymers for food packaging, Elsevier, 108-125, 2011.

19. Dosunmu, O., et al., Electrospinning of polymer nanofibres from multiple jets on a porous tubular surface, Nanotechnology, 17(4), 1123, 2006.

20. Deitzel, J., et al., Electrospinning of polymer nanofibers with specific surface chemistry, Polymer, 43(3), 1025-1029, 2002.

21. Sill, T.J. and H.A. von Recum, Electrospinning: applications in drug delivery and tissue engineering, Biomaterials, 29(13), 1989-2006, 2008.

22. Bhardwaj, N. and S.C. Kundu, Electrospinning: a fascinating fiber fabrication technique, Biotechnology advances, 28(3), 325-347, 2010.

23. Patel, D.C., Preparation and characterization of electrospun poly (D, L-Lactide-co-Glycolide) scaffolds for vascular tissue engineering and the advancement of an in vitro blood brain barrier model, 2012.

24. Haghi, A. and M. Akbari, Trends in electrospinning of natural nanofibers, Physica status solidi (a), 204(6), 1830-1834, 2007.

25. Hayati, I., A. Bailey, and T.F. Tadros, Investigations into the mechanisms of electrohydrodynamic spraying of liquids: I. Effect of electric field and the environment on pendant drops and factors affecting the formation of stable jets and atomization, Journal of Colloid and Interface Science, 117(1), 205-221, 1987.

26. Zhang, C., et al., Study on morphology of electrospun poly (vinyl alcohol) mats. European polymer journal, 41(3), 423-432, 2005.

27. Yuan, X., et al., Morphology of ultrafine polysulfone fibers prepared by electrospinning, Polymer International, 53(11), 1704-1710, 2004.

28. Megelski, S., et al., Micro-and nanostructured surface morphology on electrospun polymer fibers, Macromolecules, 35(22), 8456-8466, 2002. 
29. Buchko, C.J., et al., Processing and microstructural characterization of porous biocompatible protein polymer thin films, Polymer, 40(26), 7397-7407, 1999.

30. Ki, C.S., et al., Characterization of gelatin nanofiber prepared from gelatin-formic acid solution, Polymer, 46(14), 5094-5102, 2005.

31. Casper, C.L., et al., Controlling surface morphology of electrospun polystyrene fibers: effect of humidity and molecular weight in the electrospinning process, Macromolecules, 37(2), 573-578, 2004.

32. Khadka, D.B. and D.T. Haynie, Protein-and peptide-based electrospun nanofibers in medical biomaterials, Nanomedicine: Nanotechnology, Biology and Medicine, 8(8), 1242-1262, 2012.

33. Wang, X., et al., Controlled release of protein from core-shell nanofibers prepared by emulsion electrospinning based on green chemical, Journal of Applied Polymer Science, 132(16), 2015.

34. Jakobek, L., Interactions of polyphenols with carbohydrates, lipids and proteins, Food chemistry, 175, 556-567, 2015.

35. Anvari, M. and D. Chung, Dynamic rheological and structural characterization of fish gelatin-Gum arabic coacervate gels cross-linked by tannic acid, Food Hydrocolloids, 60, 516-524, 2016.

36. Dror, Y., et al., Nanofibers made of globular proteins, Biomacromolecules, 9(10), 2749-2754, 2008.

37. Mendes, A.C., K. Stephansen, and I.S. Chronakis, Electrospinning of food proteins and polysaccharides, Food Hydrocolloids, 68, 53-68, 2017.

38. Woerdeman, D.L., S. Shenoy, and D. Breger, Role of chain entanglements in the electrospinning of wheat protein-poly (vinyl alcohol) blends, The Journal of Adhesion, 83(8), 785-798, 2007.

39. Kriegel, C., et al., Fabrication, functionalization, and application of electrospun biopolymer nanofibers, Critical reviews in food science and nutrition, 48(8), 775-797, 2008.

40. Cho, D., A.N. Netravali, and Y.L. Joo, Mechanical properties and biodegradability of electrospun soy protein Isolate/PVA hybrid nanofibers, Polymer degradation and stability, 97(5), 747-754, 2012.

41. Wang, S., et al., Electrospun soy protein isolatebased fiber fortified with anthocyanin-rich red raspberry (Rubus strigosus) extracts, Food research international, 52(2), 467-472, 2013.

42. wen Jia, X., et al., Preparation and characterization of pea protein isolate-pullulan blend electrospun nanofiber films, International Journal of Biological Macromolecules, 2019.

43. Niu, B., et al., Electrospinning of zein-ethyl cellulose hybrid nanofibers with improved water resistance for food preservation, International journal of biological macromolecules, 142, 592$599,2020$.
44. Deng, L., et al., Encapsulation of allopurinol by glucose cross-linked gelatin/zein nanofibers: Characterization and release behavior, Food hydrocolloids, 94, 574-584, 2019.

45. Shanesazzadeh, E., M. Kadivar, and M. Fathi, Production and characterization of hydrophilic and hydrophobic sunflower protein isolate nanofibers by electrospinning method, International journal of biological macromolecules, 119, 1-7, 2018.

46. Aceituno-Medina, M., et al., Development of novel ultrathin structures based in amaranth (Amaranthus hypochondriacus) protein isolate through electrospinning, Food Hydrocolloids, 31(2), 289-298, 2013.

47. Deng, L., et al., Characterization of gelatin/zein nanofibers by hybrid electrospinning, Food Hydrocolloids, 75, 72-80, 2018.

48. Wang, H., et al., Preparation, antimicrobial and release behaviors of nisin-poly (vinyl alcohol)/wheat gluten/ZrO 2 nanofibrous membranes, Journal of Materials Science, 50(14), 5068-5078, 2015.

49. Sullivan, S.T., et al., Electrospinning and heat treatment of whey protein nanofibers, Food Hydrocolloids, 35, 36-50, 2014.

50. Kutzli, I., et al., Electrospinning of whey and soy protein mixed with maltodextrin-Influence of protein type and ratio on the production and morphology of fibers, Food hydrocolloids, 93, 206-214, 2019.

51. Talebian, A. and A. Mansourian, Release of Vancomycin from electrospun gelatin/chitosan nanofibers, Materials Today: Proceedings, 4(7), 7065-7069, 2017.

52. Lin, L., Y. Zhu, and H. Cui, Electrospun thyme essential oil/gelatin nanofibers for active packaging against Campylobacter jejuni in chicken, $L W T$, 97, 711-718, 2018.

53. Liu, Y., et al., Hydrophobic ethylcellulose/gelatin nanofibers containing zinc oxide nanoparticles for antimicrobial packaging, Journal of agricultural and food chemistry, 66(36), 9498-9506, 2018.

54. Tomasula, P.M., et al., Electrospinning of casein/pullulan blends for food-grade applications, Journal of dairy science, 99(3), 1837-1845, 2016.

55. Esparza, Y., et al., Preparation and characterization of thermally crosslinked poly (vinyl alcohol)/feather keratin nanofiber scaffolds, Materials \& Design, 133, 1-9, 2017.

56. McManus, M.C., et al., Electrospun fibrinogen: feasibility as a tissue engineering scaffold in a rat cell culture model. Journal of Biomedical Materials Research Part A: An Official Journal of The Society for Biomaterials, The Japanese Society for Biomaterials, and The Australian Society for Biomaterials and the Korean Society for Biomaterials, 81(2), 299-309, 2007.

57. Gugutkov, D., et al., Fibrinogen nanofibers for guiding endothelial cell behavior, Biomaterials science, 1(10), 1065-1073, 2013. 
58. McManus, M., et al., Electrospun nanofibre fibrinogen for urinary tract tissue reconstruction, Biomedical materials, 2(4), 257, 2007.

59. Wnek, G.E., et al., Electrospinning of nanofiber fibrinogen structures, Nano letters, 3(2), 213-216, 2013.

60. Baker, S., et al., The mechanical properties of dry, electrospun fibrinogen fibers, Materials Science and Engineering: C, 32(2), 215-221, 2012.

61. Moreira, J.B., et al., Antioxidant ultrafine fibers developed with microalga compounds using a free surface electrospinning, Food Hydrocolloids, 93, 131-136, 2019.

62. Zhong, J., et al., Electrospinning of food-grade nanofibres from whey protein, International journal of biological macromolecules, 113, 764773, 2018.

63. Park, Y.R., et al., Three-dimensional electrospun silk-fibroin nanofiber for skin tissue engineering, International journal of biological macromolecules, 93, 1567-1574, 2016.

64. Chen, Z., et al., Electrospun collagen-chitosan nanofiber: A biomimetic extracellular matrix for endothelial cell and smooth muscle cell, Acta biomaterialia, 6(2), 372-382, 2010.

65. Vega-Lugo, A.-C. and L.-T. Lim, Controlled release of allyl isothiocyanate using soy protein and poly (lactic acid) electrospun fibers, Food Research International, 42(8), 933-940, 2009.

66. Matalanis, A., O.G. Jones, and D.J. McClements, Structured biopolymer-based delivery systems for encapsulation, protection, and release of lipophilic compounds, Food Hydrocolloids, 25(8), 1865$1880,2011$.

67. Wongsasulak, S., S. Pathumban, and T. Yoovidhya, Effect of entrapped $\alpha$-tocopherol on mucoadhesivity and evaluation of the release, degradation, and swelling characteristics of zeinchitosan composite electrospun fibers, Journal of Food Engineering, 120, 110-117, 2014.

68. Mendes, A.C., et al., Hybrid electrospun chitosanphospholipids nanofibers for transdermal drug delivery, International journal of pharmaceutics, 510(1), 48-56, 2016.

69. Fabra, M.J., A. López-Rubio, and J.M. Lagaron, Use of the electrohydrodynamic process to develop active/bioactive bilayer films for food packaging applications, Food Hydrocolloids, 55, 11-18, 2016.

70. Moomand, K. and L.-T. Lim, Oxidative stability of encapsulated fish oil in electrospun zein fibres, Food research international, 62, 523-532, 2014.

71. Bui, H.T., O.H. Chung, and J.S. Park, Fabrication of electrospun antibacterial curcumin-loaded zein nanofibers, Polymer Korea, 38(6), 744-751, 2014.

72. Li, H., et al., Electrospun gelatin nanofibers loaded with vitamins $\mathrm{A}$ and $\mathrm{E}$ as antibacterial wound dressing materials, RSC advances, 6(55), 5026750277, 2016.
73. $\mathrm{Xu}, \mathrm{W}$. and Y. Yang, Drug sorption onto and release from soy protein fibers, Journal of Materials Science: Materials in Medicine, 20(12), 2477-2486, 2009.

74. Bhushani, J.A. and C. Anandharamakrishnan, Electrospinning and electrospraying techniques: Potential food based applications, Trends in Food Science \& Technology, 38(1), 21-33, 2014.

75. Wang, Z.-G., et al., Enzyme immobilization on electrospun polymer nanofibers: an overview, Journal of Molecular Catalysis B: Enzymatic, 56(4), 189-195, 2009.

76. Datta, S., L.R. Christena, and Y.R.S. Rajaram, Enzyme immobilization: an overview on techniques and support materials, 3 Biotech, 3(1), 1-9, 2013.

77. Kim, J., J.W. Grate, and P. Wang, Nanostructures for enzyme stabilization, Chemical Engineering Science, 61(3), 1017-1026, 2006.

78. Gupta, M.N., et al., Nanomaterials as matrices for enzyme immobilization, Artificial Cells, Blood Substitutes, and Biotechnology, 39(2), 98-109, 2011.

79. Kim, J., J.W. Grate, and P. Wang, Nanobiocatalysis and its potential applications, Trends in biotechnology, 26(11), 639-646, 2008.

80. Wu, L., X. Yuan, and J. Sheng, Immobilization of cellulase in nanofibrous PVA membranes by electrospinning, Journal of Membrane Science, 250(1-2), 167-173, 2005.

81. Kim, B.C., et al., Preparation of biocatalytic nanofibres with high activity and stability via enzyme aggregate coating on polymer nanofibres, Nanotechnology, 16(7), S382, 2005.

82. Jia, H., et al., Enzyme- carrying polymeric nanofibers prepared via electrospinning for use as unique biocatalysts, Biotechnology progress, 18(5), 1027-1032, 2002.

83. Kumar, T.S.M., et al., A comprehensive review of electrospun nanofibers: Food and packaging perspective, Composites Part B: Engineering, 107074, 2019.

84. Topuz, F. and T. Uyar, Antioxidant, Antibacterial and Antifungal Electrospun Nanofibers for Food Packaging Applications, Food Research International, 108927, 2019.

85. Tian, J., et al., Electrospun nanofibers for food and food packaging technology, in Electrospinning: Nanofabrication and Applications, Elsevier, 455516, 2019.

86. Shao, P., et al., Preparation of zein nanofibers with cinnamaldehyde encapsulated in surfactants at critical micelle concentration for active food packaging, Food Packaging and Shelf Life, 22, 100385, 2019.

87. Böhmer-Maas, B.W., et al., Photocatalytic zein$\mathrm{TiO} 2$ nanofibers as ethylene absorbers for storage of cherry tomatoes, Food Packaging and Shelf Life, 24, 100508, 2020. 
88. Lin, L., Y. Gu, and H. Cui, Moringa oil/chitosan nanoparticles embedded gelatin nanofibers for food packaging against Listeria monocytogenes and Staphylococcus aureus on cheese, Food Packaging and Shelf Life, 19, 86-93, 2019.

89. Sani, M.A., A. Ehsani, and M. Hashemi, Whey protein isolate/cellulose nanofibre/TiO2 nanoparticle/rosemary essential oil nanocomposite film: Its effect on microbial and sensory quality of lamb meat and growth of common foodborne pathogenic bacteria during refrigeration, International journal of food microbiology, 251, 814 ,

2017. 